\title{
Phytochemistry and medicinal properties of Psidium guajava L. leaves: A review
}

\author{
Vajira P. Bulugahapitiya*, Shanthirasekaram Kokilananthan, Harshi Manawadu \& Chinthaka Sanath \\ Gangabadage \\ Department of Chemistry, University of Ruhuna, Matara 81000, Sri Lanka \\ *Email: vajira@chem.ruh.ac.lk
}

\section{ARTICLE HISTORY}

Received: 15 June 2021

Accepted: 26 July 2021

Available online: 23 October 2021

\section{KEYWORDS}

Psidium guajava

Phytochemistry

Pharmacological activity

Chemical compositions

\begin{abstract}
Psidium guajava L. (Myrtaceae), also known as guava, is a medicinal tree native to tropical America that has been introduced and is widely available in many countries. Almost all plant parts of $P$. guajava have a long history of being used to treat a variety of ailments, in addition to applications as foods. Guava leaves are used as both medicine and food purposes, and there are numerous scientific reports on their medicinal uses, chemical composition and pharmacological properties. Cancer, blood pressure, diarrhea, bowel irregularities, diabetes, cough, cold, constipation, dysentery, scurvy, weight loss, improves skins tonicity are some of the diseases treated with guava leaves. Polyphenols, flavonoids, saponins, tannins, terpenoids, glycosides, flavones, cardiac glycosides, cardenolides, phlobatanins, steroids and other classes of bioactive compounds have been identified from the leaves. The primary chemical constituents of guava leaves are phenolic compounds, iso-flavonoids, gallic acid, catechin, quercetin, epicathechin, rutin, naringenin, kaempferol, caryophyllene oxide, p-selinene etc. Several studies have demonstrated its pharmacological activities including antioxidant, antimicrobial, antidiabetic, antitumor, anticancer, antidiarrheal, healing, cytotoxic, hepatoprotective, antiinflammatory, antimalarial/ anti-plasmodial, dental plaque, antiglycative and many more. This review is aimed on compiling all the literature reported on pharmacological activities and phytochemical compositions of guava leaves as a support to the scientific community for further studies and to provide scientific data to validate its traditional uses.
\end{abstract}

\section{Abbreviations}

ABTS: 2,2'-azino-bis (3-ethylbenzothiazoline-6-sulfonic acid, ADM: Adriamycin, $\mathrm{CH}_{3} \mathrm{Cl}$ : Chloroform, CT: Cholera toxin, CUPRAC: Cupric ions $\left(\mathrm{Cu}^{2+}\right)$ reducing ability, DPPH: 1,1-diphenyl-2-picrylhydrazyl radical, ELISA: Enzyme-linked immunosorbent assay, ELISPOT: enzyme-linked immune spot, EtOH: Ethanol, FRAP: Ferric ion reducing antioxidant power, FC: Flavonoid content, GAE: Garlic acid equivalents, IL-6: Interleukin-6, LDH: Lactate dehydrogenase, LT: Labile toxin, MeOH: Methanol, MIC: Minimum inhibitory concentration, Min: Minutes, MTT: 3-(4,5Dimethylthiazol-2-yl)-2,5-diphenyltetrazoliumbromide, OGTT: Oral glucose tolerance test, ORS: Oral rehydration saline, $\mathrm{PGE}_{2}$ : Prostaglandin $\mathrm{E}_{2}$, PMA: Phorbol myristate acetate, PSA: Prostate specific antigen, PTP1B: Protein tyrosine phosphatase 1B, QE: Quercetin equivalents, ST: Stable toxin, TBARS: Thiobarbituric acid reactive substances, TEs: Trolox equivalents, TPC: Total phenolic content, Tr: T regulatory.

\section{Background}

Psidium guajava L. also known as guava, is a fruitbearing tree from the Myrtaceae family that is native to tropical America but is now grown throughout the tropics (1). P. guajava belongs to the

Kingdom: Plantae

$$
\begin{aligned}
& \text { Division: Magnoliophyta } \\
& \text { Class: Magnoliopsida } \\
& \text { Subclass: Rosidae } \\
& \text { Order: Myrtales } \\
& \text { Family: Myrtaceae } \\
& \text { Subfamily: Myrtoideae }
\end{aligned}
$$

The bark is reddish brown, thin, smooth and flaky. The roots are extensive but only superficial. The fruit has a strong, sweet, musky odor and can be round, ovoid, or pear-shaped. The leaves are the most used

(c) Bulugahapitiya et al (2021). This is an open-access article distributed under the terms of the Creative Commons Attribution License, which permits unrestricted use, distribution and reproduction in any medium, provided the original author and source are credited (https://creativecommons.org/licenses/by/4.0/). 
part of the plant, followed by the fruits, bark and roots (2).

The leaves are used in traditional system of medicines for febrifuge, antispasmodic, wounds, ulcers and toothache, rheumatism, gargle for sore throats, laryngitis and swelling of the mouth and externally for skin ulcers, vaginal irritation, discharge, vaginal and uterine wash, especially in leucorrhoea (3). They are also used to treat diarrhea, bacterial infections, blood cleansing, astringent, lung problems, dysentery, stomach pain, antibiotics, inflammations, diabetes management, hypertension, sores, boils, cuts and sprains, as well as a boiled preparation for itchy rashes caused by scabies (2-5).

Since most of the conventional medicinal drugs have been claimed for many unwanted effects, people are looking for alternative treatments based on plants. Therefore, strengthening research on pharmacological activities of medicinal herbs is highly important in order to validate its medicinal applications. Therefore, the aim of this review is to compile the most outstanding evidences based data on phytochemistry and pharmacological activity of $P$. guajava leaves that has been published over many years.

\section{Phytochemistry of $P$. guajava leaves}

Phytochemicals are classified as either primary or secondary metabolites, depending on their role in plant metabolism. Primary metabolites include common amino acids, sugars, proteins, nucleic acid purines, pyrimidines, etc. Terpenes, alkaloids, lignans, flavonoids, plant steroids, curcumines, phenolics, saponins, flavonoids and glucosides are examples of classes of secondary metabolites (6). Guava leaves contain a wide range of phytochemicals including flavonoids, saponins, alkaloids, tannins, terpenoids, polyphenols and glycosides (7). Guava leaf extracts and essential oil have been discovered to contain a variety of individual chemical constituents, which are listed in Table 1 and Table 2. The Fig. 1 shows some of the important phytochemicals found in guava leaves [Phenolic (gallic acid (8)), Flavonoid (quercetin (9)), Ellagitannins (corilagin (10)), Tannin (pedunculagin (11)) and Terpenoid ( $\beta$-caryophyllene

(12)) respectively.

\section{Pharmacological activities of $P$. guajava leaves}

It is important to emphasize that herbal medicines are chemically complex mixtures containing multiple major and minor constituents with multiple potential targets and mechanisms in pharmacological actions. In this review, we provide detailed analysis of pharmacological studies carried out for guava leaves by various researchers and their findings with relevant literature citations, the same is briefly summarized in the Table 3.

\section{Antioxidant activity}

Antioxidant refers to a compound that can delay or inhibit the oxidation of lipids or other molecules by inhibiting the initiation or propagation of oxidative chain reactions and which can thus prevent, or repair damage done to the cells of the body by reactive oxygen species or reactive species generated from molecular oxygen. They act by one or more of the following mechanisms: reducing activity, free radicalscavenging, potential complexing of pro-oxidant metals and quenching of singlet oxygen.

It was reported that antioxidant activity and TPC is high on the order of $\mathrm{MeOH}>$ butanol > ethyl acetate $>$ hexane fractions of leaf extracts of guava (32). Further, the ABTS scavenging activities (mM TEs/mg extract): MeOH: $3.79 \pm 0.003$, butanol: $2.90 \pm 0.023$, ethyl acetate: $2.65 \pm 0.065$ and FRAP values (EC value, $\mathrm{mM} / \mathrm{mg}$ extract): $\mathrm{MeOH}: 3.65 \pm 0.038$, butanol: $1.15 \pm$ 0.132 , ethyl acetate: $1.36 \pm 0.032$ were reported for corresponding solvent extracts of guava leaves (32). Another research work revealed the presence of guavinoside $\mathrm{C}$, guavinoside $\mathrm{F}$, quercetin, quercetin-3O-a-L-arabinofuranoside, quercetin-3-O-a-L arabinopyranoside, quercetin-3-O-b-D galactopyranoside, guavinoside $\mathrm{A}$ and guavinoside $\mathrm{B}$ in the leaves and they all showed potential antioxidant activity towards the DPPH, ABTS and FRAP assays (33). It was evaluated the TPC and FC of concentrated and spray dried leaf extracts of guava with significant free radical scavenging activity towards DPPH and PMAstimulation assays (34). According to a study using lipid peroxidation assays of acetaminophen-treated rats (with reduced glutathione, catalase, glutathione peroxidase and superoxide dismutase activities) elevated levels of lipid peroxide were reduced using aqueous extract of leaves and the normalcy of glutathione peroxidase, glutathione, catalase and superoxide dismutase activities were also restored (35). There are published data on DPPH and FRAP of guava leaf extracts in different solvents and the results were summarized as follows (36). Total antioxidant capacity (based on FRAP): $\mathrm{MeOH}$ fraction: $4175.1 \mu \mathrm{mol}$ and EtOH fraction: $1733.4 \mu \mathrm{mol}$. Free radical scavenging activity (based on DPPH) - MeOH: 85.8\% > acetone: $80.8 \%$ > EtOH: $77.9 \%$ > ethyl acetate: $73.5 \%>$ Petrol ether: $51.9 \%>$ benzene: $60.8 \%$ fractions. They also conducted CUPRAC and phosphomolybdenum assays and showed comparable antioxidant activities.

\section{Antimicrobial activities}

Antimicrobial activities of water extracts of guava leaves were analyzed using paper disc-diffusion method (37) and found that the extract inhibited the growth of both reference standard strains such as Staphylococcus aureus ATCC 25923 and $b$ streptococcus group A 1000s type 28. The extract showed a stronger inhibitory effect on growth of $S$. aureus than b-streptococcus for antibiotic susceptibility testing. There are reports on the antibacterial activity assessment of leaf extracts of guava against two gram-negative bacteria (Escherichia coli and Salmonella enteritidis) and two gram-positive bacteria ( $S$. aureus and Bacillus cereus) using welldiffusion method (38). Antibacterial activities of $\mathrm{MeOH}$ and EtOH extracts against gram-positive bacteria were found to be inhibitory. $\mathrm{MeOH}$ extract had antibacterial activity against $B$. cereus and $S$. aureus with mean zones of inhibition of $8.27 \mathrm{~mm}$ and $12.3 \mathrm{~mm}$ respectively and EtOH extract had a mean zone of inhibition of $6.11 \mathrm{~mm}$ and $11.0 \mathrm{~mm}$., while gramnegative bacteria were immune to all solvent extracts ( $\mathrm{MeOH}, \mathrm{EtOH}$, hexane and water). It was found that antibacterial assays carried out against $E$. coli, $S$. 
Table 1. Chemical constituents identified in $P$. guajava leaves extracts

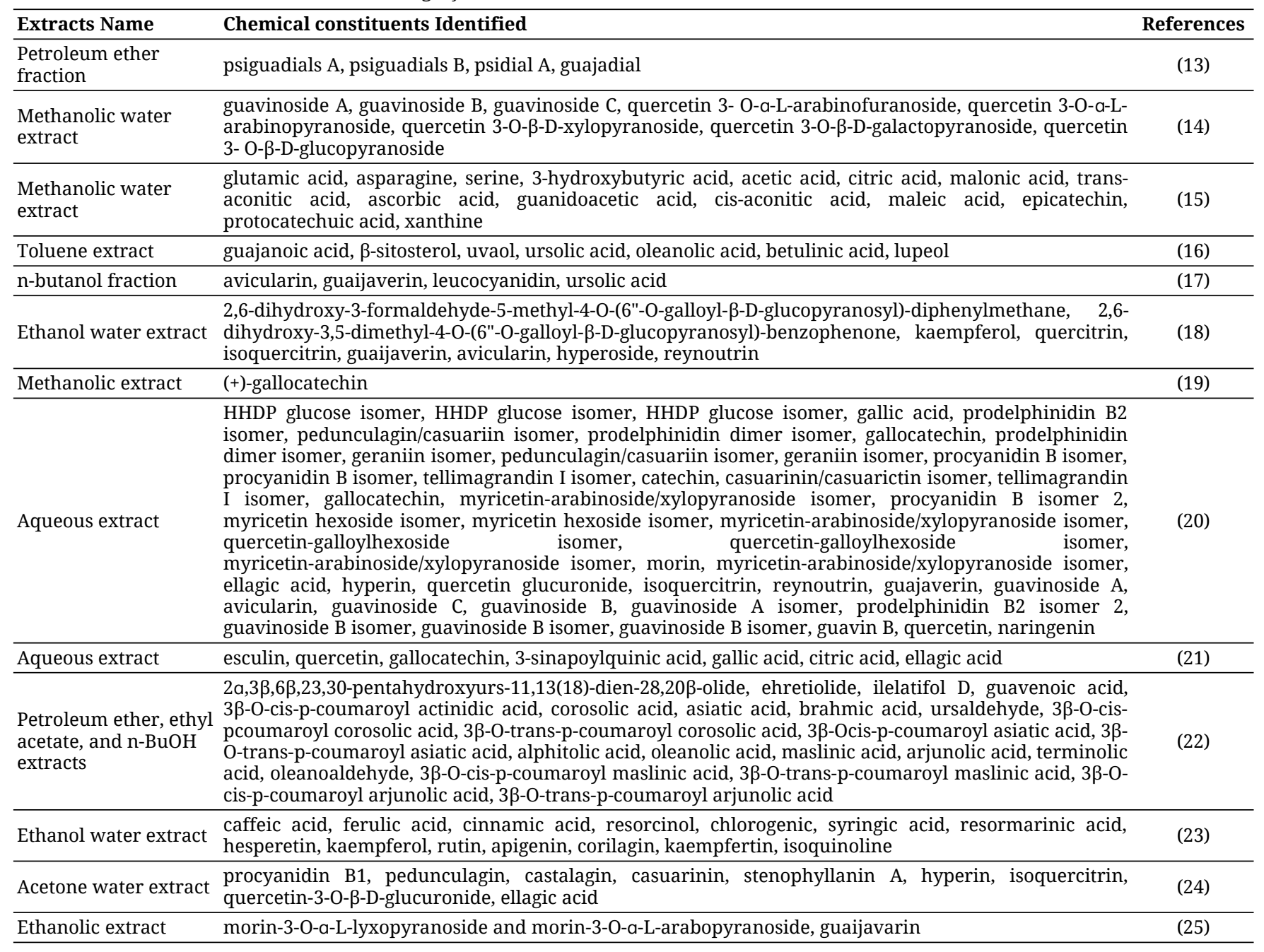

Table 2. Chemical constituents identified in essential oil of $P$. guajava leaves

\begin{tabular}{|c|c|}
\hline $\begin{array}{l}\text { Extraction } \\
\text { method }\end{array}$ & Chemical constituents identified \\
\hline $\begin{array}{l}\text { Hydro- } \\
\text { distillation }\end{array}$ & $\begin{array}{l}\text { 3-hexenol, 2-hexenol, hexanal, 2-hexenal, benzaldehyde, 3-hexenyl acetate, 6-methyl-5-hepten-2-one, linalool, a- } \\
\text { fenchol, trans-pinocarveol, borneol, terpinen-4-ol, a-terpineol, (E)-nerolidol, spathulenol, globulol, ledol, a- } \\
\text { cadinol, caryophyllenol, farnesol, a-fenchyl acetate, bornyl acetate, neryl acetate, geranyl acetate, pinocarvone, } \\
\text { 1,8-cineole, caryophyllene oxide, a-thujene, a-pinene, camphene, } \beta \text {-pinene, myrcene, a-phellandrene, a- } \\
\text { terpinene, } \rho \text {-cymene, limonene, (Z)- } \beta \text {-ocimene, } \gamma \text {-terpinene, terpinolene, allo-ocimene, a-muurolene, a-copaene, } \\
\beta \text {-caryophyllene, aromadendrene, a-humulene, allo-aromadendrene, (Z)-a-bisabolene, } \beta \text {-bisabolene, } \delta \text {-cadinene, } \\
\text { (E)- } \gamma \text {-bisabolene }\end{array}$ \\
\hline
\end{tabular}
a-pinene, $\beta$-pinene, $\delta$-2-carene, $\alpha$-phellandrene, a-terpinene, p-cymene, limonene, 1,8-cineole, cis- $\beta$-ocimene, trans- $\beta$-ocimene, $\gamma$-terpinene, terpinolene, allo-ocimene, $\alpha$-terpineol, carvacrol, $\alpha$-copaene, $\alpha$-gurjunene, $\beta$ $\begin{array}{ll}\text { Hydro- } & \text { caryophyllene, } \beta \text {-copaene, aromadendrene, } \alpha \text {-humulene, } \gamma \text {-gurjunene, chamigrene, muuroladiene, germacrene } \\ \text { distillation } & \mathrm{D}, \quad \beta \text {-selinene, } \alpha \text {-selinene, valencene, } \delta \text {-cadinene, } \alpha \text {-calamenene, } \alpha \text {-calacorene, germacrene } B \text {, viridiflorol, }\end{array}$ spathulenol, $\beta$-caryophyllene-oxide, daucol, cedr-8(15)-en-9-ol, cubenol, $\delta$-cadinol, cadalene, selin-7(11)-en-4- $\alpha$-ol, a-santalol

Hydro- $\quad$ 1,8-Cineole, (-)-a-copaene, $\beta$-Bourbonene, $\beta$-Elemene, Trans-caryophyllene, $\beta$-cubebene, $(+)$-aromandrene, a-

distillation humulene, $\beta$-humulene, $1 \mathrm{H}$-cycloprop[e]azulene, germacrene $\mathrm{D}$, calarene, trans-bisabolene, $\Delta$-cadinene, $(+)$ spathulenol, caryophyllene oxide, veridiflorol, a-cadinol, valerenol, hexadecanoic acid, isomaturnin

1-hexanol, a-pinene, camphene, $\beta$-pinene, myrcene, $\alpha$-phellandrene, $\rho$-cymene, limonene, E- $\beta$-ocimene, $\gamma$ Terpinene, $\rho$-cymenene, terpinolene, terpinen-4-ol, a-terpineol, E-piperitol, thymolmethyl ether, bornyl acetate, Hydro- neryl acetate, a-longipinene, a-copaene, 2,6-dimethoxylcymene, isocaryophyllene, $\beta$-caryophyllene, distillation aromadendrene, a-humulene, allo-aromadendrene, 4,5-di-epi-aristolochene, $\gamma$-muurolene, $\beta$-selinene, $a$ selinene, $\beta$-bisabolene, $\gamma$-cadinene, trans-calamenene, $\delta$-cadinene, cadina-1,4-diene, $\alpha$-calacorene, (E)-nerolidol, caryophyllene oxide, viridiflorol, 1 -epi-cubenol, $\tau$-cadinol, $\alpha$-cadinol

Steam a-pinene, $\beta$-pinene, $\beta$-myrcene, p-cymene, 1 ,8-cineole, borneo, terpinen-4-ol, a-terpineol, verbenone, bornyl

distillation acetate, a-copaene, $\beta$-caryophyllene, aromadendrene, a-humulene, allo-aromadendrene, myristicin, cedrenol, globulol, ledol

Supercritical n-octane, m-xylene, 1,8-cineole, $\beta$-phellandrene, a-copaene, $\beta$-caryophyllene, aromadendrene, gcrmacrene-D, $\beta$ fluid selinene, a-selinene, $\delta$-sclinene, (E)-nerolidol, (E)-nerolidol, caryophyllene epoxide, $\delta$-cadinol, alloextraction aromadendrene, ethyl hexadecanoate 
<smiles>O=C(O)c1cc(O)c(O)c(O)c1</smiles>

Gallic acid (Phenolics)<smiles>O=c1c(O)c(-c2ccc(O)c(O)c2)oc2cc(O)cc(O)c12</smiles>

Quercetin (Flavonoids)<smiles>CC1(C)C[C@H]2CC/C=C/CC[C@@H]21</smiles>

beta-caryophyllene (Terpenoids)<smiles>O=C(OC1OC2OC1C(COC(=O)c1cc(O)c(O)c(O)c1-c1c(C(=O)c3cc(O)c(O)c(O)c3)cc(O)c(O)c1O)C2O)c1cc(O)c(O)c(O)c1</smiles>

Corilagin (Ellagitannins)

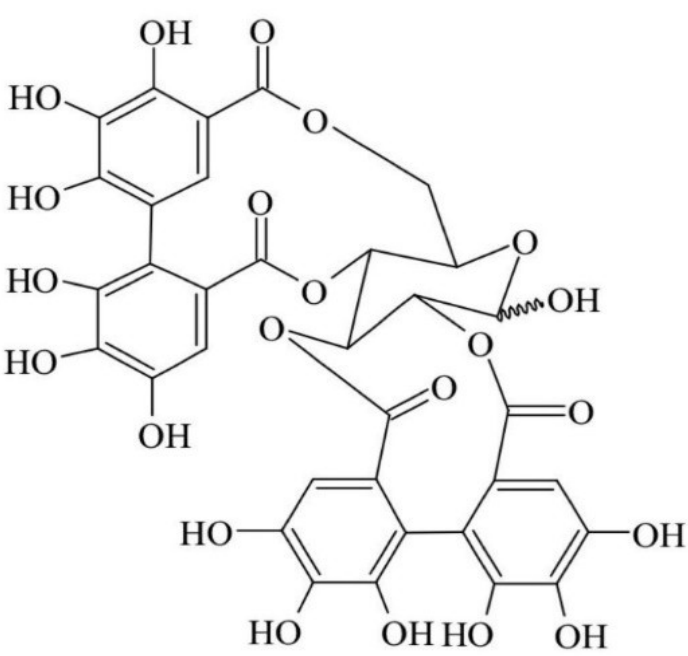

Pedunculagin (Tannins)

Fig. 1. Some of the important phytochemicals found in guava leaves.

aureus, Vibrio cholerae, Salmonella typhi, Pseudomonas aeruginosa using agar diffusion and broth dilution methods showed that $\mathrm{MeOH}$ extract is toxic to all the bacteria tested, but $S$. typhi is most sensitive, with a zone of inhibition: $2 \mathrm{~mm}$ at $4 \mathrm{mg} / \mathrm{ml}$ (39). In another antibacterial study conducted it was claimed that the aqueous extract of guava leaves is more effective than organic extracts at inhibiting the growth of pathogenic microorganisms (E. coli, $S$. pyogenes, $S$. aureus, $P$. aeruginosa and Proteus mirabilis) (40). Furthermore, gram-negative bacteria were more resistant to the effects of crude drugs. The crude extracts are more effective under acidic conditions and at low temperatures, according to diameters of growth inhibition zones. Several other works on antibacterial activities based on agar disc diffusion method revealed that $\mathrm{MeOH}$ and water extracts of guava leaves inhibited the growth of the all the tested bacteria (Salmonella typhimurium, Streptococcus suis, E. coli and Pasteurella multocida), but acetone extract exhibited inhibition zones only in colonies of $S$. suis and $P$. multocida. $\mathrm{MeOH}$ and water extracts had the same MIC against $P$. multocida $(0.156$ $\mathrm{mg} / \mathrm{ml})$, E. coli $(5 \mathrm{mg} / \mathrm{ml})$, and $S$. typhimurium (5 $\mathrm{mg} / \mathrm{ml}$ ), while acetone extract only inhibited the growth of $S$. suis and P. multocida with a MIC of 0.312 $\mathrm{mg} / \mathrm{ml}$ (41). Another two groups published their antibacterial assay data as follows. It was reported that, in agar diffusion method both aqueous and $\mathrm{MeOH}$ extracts of guava leaves showed strong antibacterial activity against multidrug-resistant $V$. cholerae (42). MIC of both extracts: $1250 \mathrm{mg} / \mathrm{ml}$ and $850 \mathrm{mg} / \mathrm{ml}$, respectively against $107 \mathrm{CFU} / \mathrm{ml}$ of $V$. cholerae. The antibacterial activity of extract is stable at $100{ }^{\circ} \mathrm{C}$ for around $15-20 \mathrm{~min}$, indicating active components are nonprotein. When $10 \mathrm{mg} / \mathrm{ml}$ (wt/v) of crude aqueous mixture was premixed with ORS in the ratio of 1:7 (volume extract/volume ORS), $V$. cholerae growth in rice ORS was fully inhibited. Interestingly, Agar disc diffusion method was used to analyze antifungal property of guava leaf extracts against Trichophyton tonsurans, Trichophyton rubrum, Candida albicans, Sporotrix schenckii, Candida parapsilosis, Cryptococcus neoformans and Microsporum canis (43). Results revealed that the hexane extract showed the strongest antifungal activity, being active against all the dermatophytes tested. Relative activity was also found in $\mathrm{MeOH}$ and acetone extracts.

\section{Antidiabetic activity}

It was reported that the in vitro studies on antidiabetic properties of guava leaf extracts that they inhibited both a-amylase and a-glucosidase enzymes (44). 
Further the extracts inhibitory effect increases in a dose-dependent manner on a-glucosidase enzyme up to $89.4 \%$ and a-amylase enzyme up to $96.3 \%$ and later publication from the same group revealed the inhibition of a-amylase and a-glucosidase enzymes by aqueous and EtOH extracts are as follows. a-amylase: 72.1 and $97.5 \%$ and a-glucosidase: 74.8 and $91.8 \%$ respectively (45). With the aid of PTP1B enzyme assay, it was reported that the antidiabetic properties of guava leaf extracts where PTP1B values were significantly inhibited by extract and histological examination of liver of Leprdb/Leprdb mice treated with butanol soluble fractions revealed large reductions in the amount of lipid droplets as compared to control mice (46). OGTT model and alloxan induced diabetic test model showed doses of $1.00 \mathrm{~g} / \mathrm{kg}$ and $0.50 \mathrm{~g} / \mathrm{kg}$ of extracts significantly $(\mathrm{P}<0.05)$ decreased blood glucose levels in the oral glucose tolerance test-model as well as $0.75 \mathrm{~g} / \mathrm{kg}$ dose in alloxan induced diabetic test-model in Wister rats $\mathrm{P}<0.001$ (47).

It is noteworthy to report on anti-hyperglycemic activities of guava leaf extracts; Anti-hyperglycemic potential against alloxan induced diabetes in rats are high in fresh leaf extract than in dry leaf extract (48). Reports are on the comparison of the antihyperglycemic properties of leaf extract to those of acarbose, a widely used diabetic medication (49). Extract had $\mathrm{IC}_{50}$ values of $50.5 \mu \mathrm{g} / \mathrm{ml}$ for a-amylase inhibition and $34.6 \mu \mathrm{g} / \mathrm{ml}$ for a-glucosidase inhibition in vitro respectively. However, the $\mathrm{IC}_{50}$ values of acarbose, for inhibiting a-amylase and a-glucosidase were $95.3 \mu \mathrm{g} / \mathrm{ml}$ and $1075.2 \mu \mathrm{g} / \mathrm{ml}$ respectively. Finally, the anti-hyperglycemic effect of extract obtained under optimal extraction conditions was higher than that of acarbose. Interestingly, hypoglycemic activity of leaf extracts of guava has also been reported (50) where they have observed statistically significant hypoglycemic activity at $250 \mathrm{mg} / \mathrm{kg}$ oral dose on alloxan induced hyperglycemia by $\mathrm{MeOH}$ extract of guava leaves in both acute and subacute tests.

\section{Antitumor and anticancer activities}

Studies are on the antitumor activities of guava extracts by cell proliferation and ELISPOT assays where, addition of extract to $\mathrm{CD} 4+$ splenocytes of C57BL/6 mice with blocked induction of Tr cells by IL10 in vitro, showed the extracts had only a mild/ no effect on production of both Th1 and Th2 cells (51). Tr cells have not been induced in splenocytes of mice when extracts were given orally. Extracts moved the Th1/ Th2 equilibrium to a Th1 dominant state by inhibiting $\operatorname{Tr}$ cell activity. Using different analysis techniques such as cell viability and expression of PSA, LDH release assay, cell cycle analysis, TUNEL assay for determination of apoptosis, western blotting analysis, gelatinolytic zymography and treatment in LNCaP prostate cancer xenograft model in nude mice, Another report showed that the aqueous extracts of guava leaves inhibit LNCaP cell growth by inducing cytotoxicity and apoptosis (52). Further it inhibited androgen receptor expression by downregulating phospho-Akt, upregulating phospho-p38 and phosphoERK1/phospho-ERK2 and arresting the cell cycle at the G1 phase. Extract significantly reduced serum PSA levels and tumor sizes in a xenografted cancer animal model. From a study that analyzed anticancer properties of leaf extracts of guava against HeLa celllines, anti-cancer response with $200 \mu \mathrm{g} / \mathrm{ml}$ of both $\mathrm{MeOH}$ and $\mathrm{CH}_{3} \mathrm{Cl}$ extracts, showing $81 \%$ and $91 \%$ inhibition respectively, while regular drug, doxorubicin, showed about $76 \%$ inhibition. In comparison, $\mathrm{CH}_{3} \mathrm{Cl}$ extract obtained better results than $\mathrm{MeOH}$ extract (53).

On final account Zhu and co-workers reported following data obtained for three potent components identified from the extract: guavinoside $B$, guavinoside E and 3,5-dihydroxy-2,4-dimethyl-1-O-(6'O-galloyl- $\beta$-D-glucopyranosyl)-benzophenone on cell viability, colony formation assays, analysis of apoptosis by flow cytometry and immunoblotting. Cell viability assay: two compounds isolated had inhibited the growth of HCT-116 human colon cancer-cell in a dose dependent manner, where one compound was more potent than the other. Cytometry analysis: one compound showed stronger activity in inducing cellular apoptosis in the cancer cells than the other. Specifically former compound increased the levels of p-ERK1/2, p53, p-JNK and cleaved caspases 8 and 9 and later compound increased the levels of p53 and cleaved caspase 8 (54).

\section{Antidiarrheal activity}

With the aid of antibacterial assays (microtiter platebased assay), effect on bacterial colonization: effect on adherence, effect on invasion, effect on bacterial enterotoxins: effect on $E$. coli heat LT and CT, effect on ST, activity against diarrhea causing bacteria was studied (55). They have reported; Decoction of leaves had antibacterial activity against $V$. cholerae and Shigella flexneri. It reduced the development of CT and LT, as well as their binding to GM1. It had no effect on development of stable toxin. Decoction also inhibited enteropathogenic $E$. coli adherence and invasion of HEp-2 cells by both enteropathogenic $E$. coli and $S$. flexneri while quercetin not showing any effect. Similar antimicrobial activity of extracts was done by another group using standard cultures of $S$. aureus (ATCC 6538) and E. coli (ATCC 15597). Diarrhea inhibition was dose-dependent and comparable to standard medication, as calculated by percentage faucal production relative to positive control. The gastrointestinal motility of extract was also reduced, as determined by the distance traveled by a charcoal plug in the small intestine. The anti-diarrhea effect of extract was thus mediated by a combination of antimicrobial activity and a decrease in gastrointestinal motility (56). Castor oil-induced diarrhea model and gastrointestinal motility test with barium sulphate milk model were carried out and it was reported that EtOH extract of leaves of guava showed antidiarrheal activity at doses of $750 \mathrm{mg} / \mathrm{kg}$ and $500 \mathrm{mg} / \mathrm{kg}$ based on the castor oil induced diarrhea model ( $\mathrm{P}<0.001$ and $\mathrm{P}<0.01$ respectively) and $750 \mathrm{mg} / \mathrm{kg}(\mathrm{P}<0.01), 500 \mathrm{mg} / \mathrm{kg}$ and $250 \mathrm{mg} / \mathrm{kg}(\mathrm{P}<0.05)$ doses in the barium sulphate milk model (47).

\section{Healing and cytotoxic effects}

It has been reported that guava leaf extracts have potential wound healing activity. Reports are on the in vivo clinical and histological evaluation of traumatic lesions in the oral mucosa of rats treated with selected 
substances (57). Following data were reported for cytotoxic studies of guava leaf extracts (33). Cytotoxic activities of isolated compounds from guava leaves such as guavinoside $\mathrm{A}, \mathrm{B}, \mathrm{C}, \mathrm{D}, \mathrm{E}$ and $\mathrm{F}$, quercetin, quercetin-3-O-a-L-arabinofuranoside, quercetin-3-O-aL-arabinopyranoside and quercetin-3-O- $\beta$-Dgalactopyranoside were investigated by MTT assay in vitro on SGC-7901, A549 and HeLa cells respectively. Compared with $\mathrm{ADM}$, which gave the $\mathrm{IC}_{50}$ values of $1.359 \mu \mathrm{g} / \mathrm{ml} 3.118 \mu \mathrm{g} / \mathrm{ml}$ and $2.684 \mu \mathrm{g} / \mathrm{ml}$ against SGC 7901, A549 and HeLa cell lines respectively. The new compound guavinoside $\mathrm{C}$ presented obvious inhibition effect on the SGC-7901, A549 and HeLa with the $\mathrm{IC}_{50}$ values of $4.277 \mu \mathrm{g} / \mathrm{ml}, 7.288 \mu \mathrm{g} / \mathrm{ml}$ and $3.246 \mu \mathrm{g} / \mathrm{ml}$ respectively and compound guavinoside $\mathrm{F}$ showed similar significant activity. Quercetin exhibited moderate inhibition against the SGC-7901 and HeLa with the $\mathrm{IC}_{50}$ values of $7.878 \mu \mathrm{g} / \mathrm{ml}$ and $8.260 \mu \mathrm{g} / \mathrm{ml}$ respectively. The other remaining compounds were not responsible clearly for cytotoxicity analysis at sample concentration less than $10 \mu \mathrm{g} / \mathrm{ml}$ (33).

\section{Hepatoprotective activity}

Serum biochemical assays and histopathological examinations of acetaminophen-treated rats (with elevated aspartate aminotransferase, alkaline phosphatase, alanine aminotransferase, total bilirubin and lowered total protein levels) showed at $500 \mathrm{mg} / \mathrm{kg}$ doses of aqueous extract of leaves reduced the elevated levels of all these biochemical parameters and significantly restored total protein normalcy (35). In acetaminophen-treated rats, lipid peroxidation increased significantly in the liver tissue, while reduced glutathione, catalase, glutathione Peroxidase and superoxide dismutase activities decreased. At doses of $500 \mathrm{mg} / \mathrm{kg}$, aqueous extract reduced elevated levels of lipid peroxide and restored glutathione peroxidase, glutathione, catalase and superoxide dismutase to usual (35). It was showed in alcoholinjured clone 9 cell viability and ALT (Hepatoprotective Assay) assays extract had a strong hepatoprotective effect on alcohol-induced liver cell injury at concentrations of $100 \mu \mathrm{g} / \mathrm{ml}$ or less (5\% alcohol for $30 \mathrm{~min}$ ) (58). The viability of cells has been shown to be reduced when ethanol concentrations are high. However, due to its higher hepatoprotective and lower cytotoxic influence, the protection provided by the hot water plant extract appears to be greater than that provided by the other plant extracts. The cytotoxic activity of extract is invariably induced at higher concentrations; hence, cautious administration is recommended.

\section{Anti-inflammatory activity}

In anti-inflammatory studies done using egg albumin $\left(\mathrm{IC}_{50}: 15.625 \mu \mathrm{g} / \mathrm{ml}\right.$ ) and bovine serum albumin ( $\mathrm{IC}_{50}: 50$ $\mu \mathrm{g} / \mathrm{ml})$, the leaf extracts showed the greatest inhibition at concentrations of $125 \mu \mathrm{g} / \mathrm{ml}$ and $500 \mu \mathrm{g} / \mathrm{ml}$ respectively. In the Bovine serum albumin denaturation test, the anti-inflammatory activity was equivalent to the reference drug, Diclofenac sodium and in the egg albumin denaturation test, it was 30fold higher than the reference drug (59). Using nitrite assay, measurement of $\mathrm{PGE}_{2}$ and IL-6 levels, ELISA, reverse transcription-polymerase chain reaction, western blot analysis, thermal hyperalgesia assessment and survival study, it was reported that guava leaf extract significantly inhibited lipopolysaccharide-induced nitric oxide and $\mathrm{PGE}_{2}$ production in a dose-dependent manner (60). Extract inhibited the expression and function of both inducible nitric-oxide synthase and cyclooxygenase-2 in RAW264.7 macrophages by inhibiting ERK1/2 activation. Furthermore, in two separate animal models, the extract showed strong anti-inflammatory activity (60). There are studies on anti-inflammatory activity against acute inflammation, subacute inflammation and chronic inflammation using four groups of mice [control; Group-A (3\% gum acacia in $10 \mathrm{ml} / \mathrm{kg}$ body weight) there were major inhibitions of paw edema in Group-B (PGE $250 \mathrm{mg} / \mathrm{kg}$ body weight), Group-C (PGE $500 \mathrm{mg} / \mathrm{kg}$ body weight) and the standard; Group-D (Aspirin $100 \mathrm{mg} / \mathrm{kg}$ body weight)] in the acute inflammation $(\mathrm{P}<0.05)(61)$. In contrast to Group-A, there were major inhibitions of exudate formation in Group-B, Group-C and Group-D during subacute inflammation. In the chronic inflammation study, the Groups-B, Group-C and Group-D showed substantial inhibition of paw edema and weight loss as compared to the Group-A. In contrast to Group-A, downregulation of the arthritis index was also notable in Group-B, Group-C and Group-D. Another research group reported leaves extract decreased inhibitory activity by $40.81 \%, 55.45 \%$ and $43.61 \%$ respectively at doses of 125,250 and $500 \mathrm{mg} / \mathrm{kg}$ body weight in carrageenan induced rat paw edema. According to this report, leaf extract has anti-inflammatory properties by reducing edema (62).

\section{Antimalarial property/ Anti-plasmodial activity}

Many studies have claimed Antimalarial property/ Anti-plasmodial activity of guava leaf extracts where, EtOH extract has anti-plasmodium activity in vitro and in vivo. Antimalarial activity of $\mathrm{EtOH}$ extract: $\mathrm{ED}_{50}$ (mg/kg body weight): $274.69 \pm 7.65, \mathrm{IC}_{50}(\mu \mathrm{g} / \mathrm{ml}): 0.6250$ \pm 0.2100 (63). In another antimalarial assay in vitro $\mathrm{IC}_{50}(\mu \mathrm{g} / \mathrm{ml})$ value of dried guava leaf extract was 8 $\mu \mathrm{g} / \mathrm{ml}$ for Plasmodium berghei while the $\left(\mathrm{IC}_{50}, \mu \mathrm{g} / \mathrm{ml}\right)$ of fresh guava leaf extract for $P$. berghei $8.2 \mu \mathrm{g} / \mathrm{ml}$. dried guava leaf extract showed higher antimalarial activity than fresh leaf extract (64). Polyherbal formulation with several different plant extracts along with guava leaf extract "Nefang" has shown excellent in vivo antimalarial activity against Plasmodium berghei and Plasmodium chabaudi parasites in acute (single dose) oral toxicity, suppressive activity (Peter's 4-day test), prophylactic activity and curative activity (Rane's test) testing (65).

\section{Dental Plaque}

Under stressed growth environments, the aqueous extract exhibited bacteriostatic effects on early dental plaque bacteria such as $S$. mitis, $S$. sanguinis and Actinomyces sp. The bacteria appeared to be unable to perform normal biological functions and ultimately ceased to propagate. Exologically, such event will regulate the formation of dental plaque (66). The treatment of early plaque settlers with a $1 \mathrm{mg} / \mathrm{ml}$ extract decreased the cell surface hydrophobicity of $S$. mitis, Actinomyces sp. and S. sanguinis by $49.9 \%, 40.6$ $\%$ and $54.1 \%$ respectively. It was also discovered that the plant extract's anti-adhesive effect on blindness of 
the early plaque settlers to the hexadecane is confounding (67).

\section{Antiglycation effect}

A group working on kinetic studies on antiglycation effects in physio mimic systems recorded that aqueous extract $(0.01-0.625 \mathrm{mg} / \mathrm{ml})$ of guava leaves was having special inhibitory characteristic on LDL glycation effect due to its high polyphenolic content (165.61 $10.39 \mathrm{mg}$ GAE/g) by determination of TBARS and TPC (68). To summarize, aqueous extract is an excellent anti-LDL glycate agent with possible therapeutic applications in the prevention of a range of cardiovascular and neurodegenerative diseases linked to glycations. It was also reported that leaf extract has shown potential antiglycative activity in a bio-model of low-density lipoproteins, which can be due to its higher polyphenolic content of leaves (69). The dose- of biochemicals present in guava leaves revealed that the plant contains a plethora of chemical compounds such as catechin, quercetin, gallic acids, epicathechin, rutin, naringenin, kaempferol, caryophyllene oxide, pselinene and others. Because of the presence of such a diverse range of chemicals, this priceless plant has a wide range of pharmacological activities that could be beneficial in treating a variety of health conditions. This review is merely an attempt to compile some of them, and as stated under its pharmacological properties, the leaf extracts have the ability to act as an antioxidant, antimicrobial, antidiabetic, antitumor, anticancer, antidiarrheal, healing, cytotoxic, hepatoprotective, anti-inflammatory, antimalarial/ anti-plasmodial, dental plaque, antiglycative and so on. This would help researchers to quickly select literature on a specific topic of interest. To sum up, guava leaves are multifunctional medicinal green

Table 3. Summary of pharmacological activities and types of guava leaf extract used for the analysis with the references.

\begin{tabular}{ll}
\hline Pharmacological activities & Type of extract used \\
\hline Antioxidant activity & $\begin{array}{l}\text { Ethanol, aqueous, petroleum ether, benzene, ethyl acetate, methanol } \\
\text { extracts }\end{array}$ \\
\hline Antimicrobial activity & Aqueous, ethanol, methanol, hexane, acetone extracts \\
\hline Antidiabetic activity & $\begin{array}{l}\text { Methanol, aqueous, ethanol, hexane, petroleum ether, chloroform, } \\
\text { butanol, ethyl acetate extracts }\end{array}$ \\
\hline Antitumor and Anticancer Activities & Ethanol, aqueous, methanol, chloroform extracts \\
\hline Antidiarrheal activity & Ethanol, aqueous extracts \\
\hline Healing and cytotoxic effects & Ethanol extract \\
\hline Hepatoprotective activity & Aqueous, acetone, ethanol extracts \\
\hline Anti-inflammatory activity & Aqueous, ethanol extracts \\
\hline Antimalarial property/ Anti-plasmodial & Ethanol, aqueous extracts \\
\hline activity & Aqueous extract \\
\hline Dental Plaque & Aqueous extract \\
\hline Antiglycation effect & (33, 57) \\
\hline
\end{tabular}

dependent inhibition models were validated using computer simulation. Extract contains a high concentration of polyphenolic compounds Catechin, gallic acid, epicatechin, quercetin, rutin, kaempferol and naringenin are the seven main compounds present in guava leaf extract., whose antiglycative bioactivity is consistent with the inhibition models (kinetic studies) using TBARS studies (69).

Table 3 summarizes individual pharmacological activities, the nature of the extracts and the corresponding references discussed above. This review will be the first and comprehensive scientific repository of guava leaves as this gives a broad analysis of phytochemistry and pharmacological activity of guava leaf including chemical compositions of different guava leaf extracts and essential oil, and pharmacological activities with sufficient proven data.

\section{Conclusion}

This review provides literature data on in-depth studies of Guava (P. guajava) leaves for biochemical composition and pharmacological activities. In general, it contains a variety of chemical constituents such as alkaloids, polyphenolic compounds, saponins, tannins, flavonoids, terpenoids, carbohydrates, lipids, fats and oils, as well as various types of glycosides, amino acids, etc. Furthermore, structure elucidation sources with a diverse array of potent secondary metabolites.

\section{Acknowledgements}

Authors greatly acknowledge AHEAD/RUH/DOR-05 grant for the financial support.

\section{Authors' contributions}

All the authors have contributed for collecting research literature and preparation of the manuscript.

\section{Compliance with ethical standards}

Conflict of interest: The authors declare that they have no conflicts of interest regarding the publication of this paper.

Ethical issues: None.

\section{References}

1. Barbalho SM, Farinazzi-Machado FMV, Goulart RA, Brunnati ACS, Ottoboni AMMB, Nicolau CCT. Psidium guajava (Guava): A plant of multipurpose medicinal applications. Med Aromat Plants. 2012;1(4):1-6. http://dx.doi.org/10.4172/2167-0412.1000104 
2. Gupta GK, Chahal J, Arora D. Psidium guajava Linn.: Current research and future prospects. J Pharm Res. 2011;4(1):42 46.

3. Gutiérrez RMP, Mitchell S, Solis RV. Psidium guajava: a review of its traditional uses, phytochemistry and pharmacology. J Ethnopharmacol. 2008;117(1):1-27. https://doi.org/10.1016/ j.jep.2008.01.025

4. Geidam YA, Ambali AG, Onyeyili PA. Preliminary phytochemical and antibacterial evaluation of crude aqueous extract of Psidium guajava leaf. J Appl Sci. 2007;7(4):511-14. https://doi.org/10.3923/ jas.2007.511.514

5. Sanda KA, Grema HA, Geidam YA, Bukar-Kolo YM. Pharmacological aspects of Psidium guajava: An update. Int J Pharmacol. 2011;7:316-24. https://doi.org/10.3923/ijp.2011.316.324

6. Saxena M, Saxena J, Nema R, Singh D, Gupta A. Phytochemistry of medicinal plants. J Pharmacogn Phytochem. 2013;1(6):168-82.

7. Gayathri V, Kiruba D. Preliminary phytochemical analysis of leaf powder extracts of Psidium guajava L. Int J Pharmacogn Phytochem Res. 2014;6(2):332-34.

8. Nawaz R, Chong F, Ho Y, Isa M, Lim W. Restoration of pretreated palm oil mill effluent using $\mathrm{TiO}_{2}$ based photocatalytic system: An optimization study. In: IOP Conference Series: Materials Science and Engineering. IOP Publishing; 2020; pp 01-09. https://doi.org/ 10.1088/1757-899X/736/4/042035

9. Prieto-Vila M, Shimomura I, Kogure A, Usuba W, Takahashi R-u, Ochiya T et al. Quercetin inhibits Lef1 and resensitizes docetaxelresistant breast cancer cells. Molecules. 2020;25(11):1-11. https:/ doi.org/10.3390/molecules25112576

10. Deng Y, Li X, Li X, Zheng Z, Huang W, Chen L et al. Corilagin induces the apoptosis of hepatocellular carcinoma cells through the mitochondrial apoptotic and death receptor pathways. Oncol Repo. 2018;39:2545-52. https://doi.org/10.3892/or.2018.6396

11. Silva RM, Pereira LD, Véras JH, Vale CR, Chen-Chen L, Santos SC. Protective effect and induction of DNA repair by Myrciaria cauliflora seed extract and pedunculagin on cyclophosphamideinduced genotoxicity. Mutat Res Genet Toxicol and Environ Mutagen. 2016;810:40-47. https://doi.org/10.1016 j.mrgentox.2016.10.001

12. Grozdev L, Kaiser J, Berensmeier S. One-step purification of microbially produced hydrophobic terpenes via process chromatography. Front in Bioeng Biotechnol. 2019;7:1-12. https://doi.org/ 10.3389/fbioe.2019.00185

13. Shao M, Wang Y, Liu Z, Zhang D-M, Cao H-H, Jiang R-W et al. Psiguadials A and B, two novel meroterpenoids with unusual skeletons from the leaves of Psidium guajava. Org Lett. 2010;12(21):5040-43. https://doi.org/10.1021/ol102179u

14. Matsuzaki K, Ishii R, Kobiyama K, Kitanaka S. New benzophenone and quercetin galloyl glycosides from Psidium guajava L. J Nat Med. 2010;64:252-56. https://doi.org/10.1007/s11418-010-0400-2

15. Kim S-H, Cho SK, Hyun S-H, Park H-E, Kim Y-S, Choi H-K. Metabolic profiling and predicting the free radical scavenging activity of guava (Psidium guajava L.) leaves according to harvest time by 1H-nuclear magnetic resonance spectroscopy. Biosci Biotechnol Biochem. 2011;75(6):1090-97. https://doi.org/10.1271/bbb.100908

16. Ghosh P, Mandal A, Chakraborty P, Rasul M, Chakraborty M, Saha A. Triterpenoids from Psidium guajava with biocidal activity. Indian J Pharm Sci. 2010;72(4):504-07. https://doi.org/10.4103/0250474X.73936

17. Kim M-H, Kim JN, Han SN, Kim H-K. Ursolic acid isolated from guava leaves inhibits inflammatory mediators and reactive oxygen species in LPS-stimulated macrophages. Immunopharmacol Immunotoxicol. 2015;37(3):228-35. https://doi.org/ $10.3109 / 08923973.2015 .1021355$

18. Shu J-C, Chou G-X, Wang Z-T. One new diphenylmethane glycoside from the leaves of Psidium guajava L. Nat Prod Res. 2012;26(21):1971-75. https://doi.org/10.1080/14786419.2011.633081

19. Matsuo T, Hanamure N, Shimoi K, Nakamura Y, Tomita I. Identification of (+)-gallocatechin as a bio-antimutagenic compound in Psidium guajava leaves. Phytochemistry. 1994;36(4):1027-29. https://doi.org/10.1016/S0031-9422(00)90484-9

20. Díaz-de-Cerio E, Verardo V, Gómez-Caravaca AM, FernándezGutiérrez A, Segura-Carretero A. Determination of polar compounds in guava leaves infusions and ultrasound aqueous extract by HPLC-ESI-MS. J Chem. 2015;2015: 1-9. https://doi.org/ $10.1155 / 2015 / 250919$

21. Kumar NS, Sarbon NM, Rana SS, Chintagunta AD, Prathibha S, Ingilala SK et al. Extraction of bioactive compounds from Psidium guajava leaves and its utilization in preparation of jellies. AMB Express. 2021;11:1-9. https://doi.org/10.1186/s13568-021-01194-9

22. Li Y, Xu J, Li D, Ma H, Mu Y, Zheng D et al. Chemical characterization and hepatoprotective effects of a standardized triterpenoidenriched guava leaf extract. J Agri Food Chem. 2021;69(12):362637. https://doi.org/10.1021/acs.jafc.0c07125

23. Taha TF, Elakkad HA, Gendy AS, Abdelkader MA, Hussein SE. In vitro bio-medical studies on Psidium guajava leaves. Plant Arch. 2019;19(1):199-207.

24. Yamanaka F, Hatano T, Ito H, Taniguchi S, Takahashi E, Okamoto K. Antibacterial effects of guava tannins and related polyphenols on Vibrio and Aeromonas species. Nat Prod Commun. 2008;3(5):711-20. https://doi.org/10.1177/1934578X0800300509

25. Eidenberger T, Selg M, Krennhuber K. Inhibition of dipeptidyl peptidase activity by flavonol glycosides of guava (Psidium guajava L.): a key to the beneficial effects of guava in type II diabetes mellitus. Fitoterapia. 2013;89:74-79. https://doi.org/10.1016/j.fitote.2013.05.015

26. Chen H-C, Sheu M-J, Lin L-Y, Wu C-M. Chemical composition of the leaf essential oil of Psidium guajava L. from Taiwan. J Essent Oil Res. 2007;19(4):345-47. https://doi.org/10.1080/10412905.2007.9699300

27. El-Ahmady SH, Ashour ML, Wink M. Chemical composition and anti-inflammatory activity of the essential oils of Psidium guajava fruits and leaves. J Essent Oil Res. 2013;25(6):475-81. https:// doi.org/10.1080/10412905.2013.796498

28. Khadhri A, Mokni RE, Almeida C, Nogueira J, Araújo MEM. Chemical composition of essential oil of Psidium guajava L. growing in Tunisia. Ind Crops Prod. 2014;52:29-31. https://doi.org/10.1016/j.indcrop.2013.10.018

29. Ogunwande IA, Olawore NO, Adeleke KA, Ekundayo O, Koenig WA. Chemical composition of the leaf volatile oil of Psidium guajava L. growing in Nigeria. Flavour Fragr J. 2003;18(2):136-38. https://doi.org/10.1002/ffj.1175

30. Ji X, Pu Q, Garraffo HM, Pannell LK. The Essential Oil of the Leaves of Psidium guajava L. J Essent Oil Res. 1991;3(3):187-89. https://doi.org/10.1080/10412905.1991.9700501

31. Sagrero-Nieves L, Bartley JP, Provis-Schwede A. Supercritical fluid extraction of the volatile components from the leaves of Psidium guajava L. (guava). Flavour Fragr J. 1994;9(3):135-37. https:// doi.org/10.1002/ffj.2730090309

32. Tachakittirungrod S, Okonogi S, Chowwanapoonpohn S. Study on antioxidant activity of certain plants in Thailand: Mechanism of antioxidant action of guava leaf extract. Food Chem. 2007;103(2):381-88. https://doi.org/10.1016/j.foodchem.2006.07.034

33. Feng X-h, Wang Z-h, Meng D-l, Li X. Cytotoxic and antioxidant constituents from the leaves of Psidium guajava. Bioorg Med Chem Lett. 2015;25(10):2193-98. https://doi.org/10.1016/ j.bmcl.2015.03.058

34. Fernandes MRV, Azzolini AECS, Martinez MLL, Souza CRF, Lucisano-Valim YM, Oliveira WP. Assessment of antioxidant activity of spray dried extracts of Psidium guajava leaves by DPPH and chemiluminescence inhibition in human neutrophils. Biomed Res Int. 2014;2014:1-10. https://doi.org/10.1155/2014/382891

35. Taju G, Jayanthi M, Majeed SA. Evaluation of hepatoprotective and antioxidant activity of Psidium guajava leaf extract against acetaminophen induced liver injury in rats. Int J Toxicol Appl Pharmacol. 2011;1:13-20.

36. Zahin M, Ahmad I, Aqil F. Antioxidant and antimutagenic potential of Psidium guajava leaf extracts. Drug Chem Toxicol. 2017;40(2):146-53. https://doi.org/10.1080/01480545.2016.1188397

37. Jaiarj P, Khoohaswan P, Wongkrajang Y, Peungvicha P, Suriyawong P, Saraya MLS et al. Anticough and antimicrobial activities of Psidium guajava Linn. leaf extract. J Ethnopharmacol. 1999;67(2):203-12. https://doi.org/10.1016/S0378-8741(99)00022-7

38. Biswas B, Rogers K, McLaughlin F, Daniels D, Yadav A. Antimicrobial activities of leaf extracts of guava (Psidium guajava L.) on two gram-negative and gram-positive bacteria. Int J Microbiol. 2013;2013:1-7. http://dx.doi.org/10.1155/2013/746165 
39. Choudhury S, Sharan L, Sinha MP. Phytochemical and antimicrobial screening of Psidium guajava L. leaf extracts against clinically important gastrointestinal pathogens. J Nat Prod Plant Resour. 2012;2:524-29.

40. Abubakar EM. The use of Psidium guajava Linn. in treating wound, skin and soft tissue infections. Sci Res Essays. 2009;4(6):605-11. https://doi.org/10.5897/SRE.9000951

41. Puntawong S, Okonogi S, Pringproa K. In vitro antibacterial activity of Psidium guajava Linn. leaf extracts against pathogenic bacteria in pigs. Chiang Mai Univ J Nat Sci. 2012;11(2):127-34.

42. Rahim N, Gomes DJ, Watanabe H, Rahman SR, Chomvarin C Endtz HP et al. Antibacterial activity of Psidium guajava leaf and bark against multidrug-resistant Vibrio cholerae: implication for cholera control. Jap J Infect Dis. 2010;63:271-74.

43. Beatriz P-M, Ezequiel V-V, Azucena O-C, Pilar C-R. Antifungal activity of Psidium guajava organic extracts against dermatophytic fungi. J Med Plants Res. 2012;6(41):5435-38. https://doi.org/ 10.5897/JMPR12.240

44. Manikandan R, Anand AV, Muthumani GD. Phytochemical and in vitro anti-diabetic activity of methanolic extract of Psidium guajava leaves. Int J Curr Microbiol Appl Sci. 2013;2(2):15-19.

45. Manikandan R, Anand AV, Kumar S, Pushpa. Phytochemical and in vitro antidiabetic activity of Psidium guajava leaves. Pharmacogn J. 2016;8(4):392-94. https://doi.org/10.5530/pj.2016.4.13

46. Oh WK, Lee CH, Lee MS, Bae EY, Sohn CB, Oh $\mathrm{H}$ et al. Antidiabetic effects of extracts from Psidium guajava. J Ethnopharmacol. 2005;96(3):411-15. https://doi.org/10.1016/j.jep.2004.09.041

47. Mazumdar S, Akter R, Talukder D. Antidiabetic and antidiarrhoeal effects on ethanolic extract of Psidium guajava (L.) Bat. leaves in Wister rats. Asian Pac J Trop Biomed. 2015;5(1):10-14. https://doi.org/10.1016/S2221-1691(15)30163-5

48. Rapaka D, Vennam S. Evaluation and comparison of anti-diabetic activity of hydroalcoholic extracts of fresh and dry leaves of Psidium guajava in type-ii diabetes mellitus. Int Res J Pharm Appl Sci. 2012;2(4):62-65.

49. Liu C-W, Wang Y-C, Lu H-C, Chiang W-D. Optimization of ultrasound-assisted extraction conditions for total phenols with antihyperglycemic activity from Psidium guajava leaves. Process Biochem. 2014;49(10):1601-05. https://doi.org/10.1016/ j.procbio.2014.06.009

50. Mukhtar HM, Ansari SH, Naved T, Bhat ZA. Hypoglycemic activity of Psidium guajava Linn. leaf extract. J Nat Remedies. 2004;4(2):186-89. https://doi.org/10.18311/jnr/2004/186

51. Seo N, Ito T, Wang N, Yao X, Tokura Y, Furukawa F et al. Anti-allergic Psidium guajava extracts exert an antitumor effect by inhibition of $\mathrm{T}$ regulatory cells and resultant augmentation of Th1 cells. Anticancer Res. 2005;25:3763-70.

52. Chen K-C, Peng C-C, Chiu W-T, Cheng Y-T, Huang G-T, Hsieh C-L et al. Action mechanism and signal pathways of Psidium guajava $\mathrm{L}$. aqueous extract in killing prostate cancer LNCaP cells. Nutr Cancer. 2010;62(2):260-70. https://doi.org/10.1080/01635580903407130

53. Muhammad A, Tayyab AM, Hassan S, Nadeem AM, Musharraf A. The phytochemical and comparative anticancer study of methanolic and chloroform extracts of Psidium guajava L. leaves of Pakistani origin. J Drug Deliv Ther. 2020;10(1-s):149-53. http:// dx.doi.org/10.22270/jddt.v10i1-s.3922

54. Zhu X, Ouyang W, Pan C, Gao Z, Han Y, Song M et al. Identification of a new benzophenone from Psidium guajava L. leaves and its antineoplastic effects on human colon cancer cells. Food Funct. 2019;10(7):4189-98. https://doi.org/10.1039/C9FO00569B

55. Birdi T, Daswani P, Brijesh S, Tetali P, Natu A, Antia N. Newer insights into the mechanism of action of Psidium guajava L. leaves in infectious diarrhoea. BMC Complement Altern Med. 2010;10(33):1-11. https://doi.org/10.1186/1472-6882-10-33

56. Ezekwesili JO, Nkemdilim UU, Okeke CU. Mechanism of antidiarrhoeal effect of ethanolic extract of Psidium guajava leaves. Biokemistri. 2010;22(2):85-90.

57. Fernandes KPS, Bussadori SK, Marques MM, Wadt NSY, Bach E, Martins MD. Healing and cytotoxic effects of Psidium guajava (Myrtaceae) leaf extracts. Braz J Oral Sci. 2010;9:449-54.
58. Chen H-H, Wu P-H, Lo D, Pan Y-C, Wu M-C. Hepatoprotective effect of guava (Psidium guajava L.) leaf extracts on ethanol-induced injury on clone 9 rat liver cells. Food Nutr Sci. 2011;2(9):983-88. https://doi.org/10.4236/fns.2011.29133

59. Kariawasam KWJC, Pathirana RN, Ratnasooriya WD, Handunnetti $\mathrm{S}$, Abeysekera WPKM. Phytochemical profile and in vitro anti-inflammatory activity of aqueous leaf extract of Sri Lankan variety of Psidium guajava L. J Pharmacogn Phytochem. 2017;6(4):22-26.

60. Jang M, Jeong S-W, Cho SK, Ahn KS, Lee JH, Yang DC et al. Anti-inflammatory effects of an ethanolic extract of guava (Psidium guajava L.) leaves in vitro and in vivo. J Med Food. 2014;17(6):678-85. https://doi.org/10.1089/jmf.2013.2936

61. Dutta S, Das S. A study of the anti-inflammatory effect of the leaves of Psidium guajava Linn. on experimental animal models. Pharmacogn Res. 2010;2(5):313-17. https://doi.org/10.4103/09748490.72331

62. Weni L, Harliansyah H, Widayanti W. Anti-inflammatory activity of the extract of guava leaves (Psidium guajava $\mathrm{L}$ ) in the rat (Rattus norvegicus L). Indonesian J Cancer Chemoprevention. 2011;2(1):169-72. http://dx.doi.org/10.14499/indonesianjcanchemoprev2iss1pp169-172

63. Abdillah S, Tambunan RM, Farida Y, Sandhiutami NMD, Dewi RM. Phytochemical screening and antimalarial activity of some plants traditionally used in Indonesia. Asian Pac J Trop Dis. 2015;5(6):454-57. https://doi.org/10.1016/S2222-1808(15)60814-3

64. Chinchilla M, Valerio I, Sánchez R, Mora V, Bagnarello V, Martínez $\mathrm{L}$ et al. In vitro antimalarial activity of extracts of some plants from a biological reserve in Costa Rica. Rev Biol Trop. 2012;60(2):881-91.

65. Tarkang PA, Okalebo FA, Ayong LS, Agbor GA, Guantai AN. Antimalarial activity of a polyherbal product (Nefang) during early and established Plasmodium infection in rodent models. Malar J. 2014;13(1):456.

66. Fathilah AR, Rahim ZH, Othman Y, Yusoff M. Bacteriostatic effect of Piper betle and Psidium guajava extracts on dental plaque bacteria. Pak J Biol Sci. 2009;12(6):518-21. https://doi.org/10.3923/ pjbs.2009.518.521

67. Razak FA, Othman RY, Rahim ZHA. The effect of Piper betle and Psidium guajava extracts on the cell-surface hydrophobicity of selected early settlers of dental plaque. J Oral Sci. 2006;48(2):71-75. https://doi.org/10.2334/josnusd.48.71

68. Hsieh C-L, Yang M-H, Chyau C-C, Chiu C-H, Wang H-E, Lin Y-C et al. Kinetic analysis on the sensitivity of glucose-or glyoxal-induced LDL glycation to the inhibitory effect of Psidium guajava extract in a physiomimic system. Biosystems. 2007;88:92-100. https:// doi.org/10.1016/j.biosystems.2006.04.004

69. Chen K-C, Chuang C-M, Lin L-Y, Chiu W-T, Wang H-E, Hsieh C-L et al. The polyphenolics in the aqueous extract of Psidium guajava kinetically reveal an inhibition model on LDL glycation. Pharm Biol. 2010;48(1):23-31. https://doi.org/10.3109/13880200903029365

\section{Additional information}

Peer review information: Plant Science Today thanks Sectional Editor and the other anonymous reviewers for their contribution to the peer review of this work.

Reprints and permissions information is available at https://horizonepublishing.com/journals/index.php/PST/open_access_policy

Publisher's Note: Horizon e-Publishing Group remains neutral with regard to jurisdictional claims in published maps and institutional affiliations.

To cite this article: Bulugahapitiya $\mathrm{V} \mathrm{P}$, Kokilananthan S, Manawadu $\mathrm{H}$, Gangabadage C S. Phytochemistry and medicinal properties of Psidium guajava leaves: A review. Plant Science Today. 2021;8(4):963-971. https://doi.org/ 10.14719/pst.2021.8.4.1334

Plant Science Today, published by Horizon e-Publishing Group, is covered by Scopus, Web of Science, BIOSIS Previews, Clarivate Analytics, etc. See https:// horizonepublishing.com/journals/index.php/PST/indexing_abstracting 